\title{
PENGARUH PEMBERIAN FORMALIN PERORAL TERHADAP MUKOSA LAMBUNG TIKUS PUTIH STRAIN WISTAR (RATTUS NORVEGICUS STRAIN WISTAR)
}

\author{
Muhammad Fadhol Romdhoni \\ Laboratorium Farmakologi, Fakultas Kedokteran, Universitas Muhammadiyah Purwokerto \\ Email : fadhol.romdhoni@gmail.com
}

\begin{abstract}
Abtrak
Objektif : Gastritis merupakan salah satu penyakit paling banyak dijumpai di klinik, pada tahun 2001 prevalensi gastritis kronik di Indonesia 4,3 \% dari rata - rata 100.000 populasi dan salah satu penyebabnya adalah zat aditif seperti formalin. Formalin banyak disalahgunakan terutama dibidang industri makanan, bila dikonsumsi akan menyebabkan kelainan pada tubuh. Tujuan penelitian ini adalah membuktikan pengaruh formalin peroral subakut terhadap mukosa lambung tikus putih strain wistar (Rattus norvegicus strain wistar).

Metode \& Sampel : Penelitian ini merupakan eksperimental murni, dengan rancangan The Posttest Control Group Desain. Sampel penelitian adalah tikus putih strain wistar yang dibagi dalam 4 kelompok. Kelompok I sebagai kontrol tanpa pemberian formalin dan kelompok lainnya diberi formalin dosis 20 ppm, 40 ppm dan 80 ppm.

Hasil \& Pembahasan : Hasil yang didapat dari penelitian adalah pemberian formalin menyebabkan hiperplasia, hipertropi, atropi, radang (ANOVA p $=0,000$ ). Pengaruh pemberian formalin terhadap perubahan sel mukosa lambung tikus diduga terikatnya formalin dengan protein DNA sehingga mengganggu ekspresi genetik.

Kesimpulan : Pada penelitian ini dapat disimpulkan bahwa pemberian formalin terbukti dapat menyebabkan perubahan sel mukosa lambung tikus putih strain wistar, dan diperlukan penelitian lanjutan untuk mengetahui dosis minimal yang mengakibatkan perubahan sel mukosa lambung serta bagaimana mekanismenya.
\end{abstract}

Kata kunci : Gastritis; formalin; Mukosa lambung; tikus. 


\section{Abstract}

Objective : Gastritis represent one of more disease in clinic, on 2001 prevalention of cronic gastritis in Indonesia 4.3\% of 100.000 population and caused additive like formaldehyde. Formaldehyde was misused especially in food industry, if consumed can cause organ's disparity. Intention of this research is prove the Effect of Formaldehyde peroral subacute on the stomach mucosal of White Rat Strain Wistar (Rattus Norvegicus strain wistar)

Method \& Materials : The design of the study was pure experimental which using The Posttest Control Group Design. Sample were white mice which divided into 4 groups. Group I is as a control, without formaldehyde, and another groups were given with formaldehyde doses $20 \mathrm{ppm}, 40 \mathrm{ppm}$, and $80 \mathrm{ppm}$.

Result and discussion : The results should that formaldehyde can cause hyperplasia, hypertrophic, atopic, chafe (ANOVA $\mathrm{p}=0.000$ ). The mechanism of action possibility as DNA cross-linked by protein than gene expression anormal.

Conclusions : The study concluded that formaldehyde can cause hyperplasia, hypertrophic, atopic, and chafe on the mucosal stomach of white rat strain wistar and further study was needed to know minimum doses than can change of stomach mucosal and than mecahanism of action about them.

Key Words: Gastritis, formaldehyde, stomach mucosal; rat

\section{PENDAHULUAN}

Gastritis merupakan salah satu penyakit paling banyak dijumpai di klinik. ${ }^{9}$ Studi epidemiologi membuktikan bahwa insiden gastritis menyebar secara luas. Di Amerika Serikat dilaporkan sekitar 1,8 - 2,1 juta orang yang berobat ke dokter di diagnosis gastritis. ${ }^{19}$ Pada tahun 2001 prevalensi gastritis kronik di Indonesia 4,3 $\%$ dari rata - rata 100.000 populasi. $^{23}$

Gastritis merupakan kelainan radang pada lambung, dibagi menjadi gastritis akut dan gastritis kronik. Gastritis akut merupakan suatu keadaan peradangan yang terjadi pada mukosa lambung. ${ }^{19}$ Gambaran patologis dari gastritis akut meliputi degenerasi epitel permukaan, hiperplasia regeneratif epitel pembatas permukaan, vasodilatasi / kongesti, dan respon neutrofil polimorfonuklear. ${ }^{16}$ Hiperplasia merupakan suatu peningkatan jumlah sel yang terdapat pada organ atau jaringan yang mungkin juga disertai dengan peningkatan volume secara mitosis. ${ }^{3}$ Sel yang bermitosis akan berhenti pada tingkat tertentu supaya sesuai dengan kebutuhan tubuh dengan mekanisme pengontrolan pertumbuhan jaringan oleh induksi atau penghambatan apoptosis. Apabila mekanisme ini terganggu maka sel akan membelah secara terusmenerus sehingga jumlah sel bertambah banyak melebihi kebutuhan tubuh. ${ }^{16}$ Gastritis kronik yang paling banyak ditemukan ialah karena infeksi Helicobacter pylori. Respon radang akut yang dibangkitkan oleh $H$. pylori dapat menyebabkan destruksi kelenjar (terjadi atropi). Gastritis kronik merupakan penyebab tersering dari kanker lambung.

Gastritis dapat disebabkan oleh beberapa faktor diantaranya beberapa golongan obat, alkohol, empedu, iskemia, bakteri, virus, jamur, stres akut, radiasi, alergi, trauma langsung, dan keracunan makanan atau zat aditif pada makanan, seperti formalin. ${ }^{19}$

Formalin banyak disalahgunakan terutama di bidang industri makanan. Di Jakarta, kandungan formalin dapat ditemukan pada mie basah, tahu, ikan asin, mi keriting, mie ayam super, dan kwe tiaw dengan konsentrasi antara $3-400 \mathrm{ppm}$. Selain itu formalin juga didapatkan pada produk plastik dan sterofoam. Kadarnya mencapai 5 ppm. ${ }^{1}$ Padahal menurut OSHA (Occupational Safety and Health Administration) batas yang bisa ditoleransi oleh tubuh adalah 0,75 ppm, sedangkan menurut NIOSH (The National Institute for Occupational Safety and Health) adalah 0,016 ppm dan menurut ACGIH (The American Conference of Governmental Industrial Hygienists) adalah 0,3 ppm. ${ }^{15}$

Pada studi yang dilakukan pada tikus putih strain wistar secara kronik (selama 2 tahun) dengan 
memberikan formalin dengan dosis 0, 1.2, 15, 82 ppm/ hari didapatkan perubahan patologis pada permukaan mukosa lambung dan usus halus antara lain papillary hyperplasia dan hiperkeratosis permukaan mukosa lambung, atropik gastritis, serta ulserasi dan hiperplasia dari mukosa lambung. ${ }^{21}$ Pada penelitian yang lain, tikus putih jantan strain wistar secara subakut dengan memberikan formalin dengan dosis $0,20,40,80 \mathrm{ppm} /$ hari didapatkan perubahan sistem hematologi serta berat dari timus, ginjal, dan hepar. Disamping itu juga dilakukan pengamatan selularitas dari limfonodi dan limpa. ${ }^{17}$ Sedangkan penelitian tentang pengaruh formalin lambung belum pernah dilakukan, sehingga timbul pertanyaan apakah pemberian formalin peroral subakut dapat memberikan efek patologis pada lambung. ${ }^{4}$

\section{METODE PENELITIAN}

Penelitian ini adalah penelitian eksperimental dan rancangan penelitian yang digunakan adalah The Post Test Only Control Group Design, dilakukan selama 4 minggu (sub akut).

Populasi dari penelitian ini adalah seluruh tikus putih strain wistar (Rattus norvegicus strain wistar). Sampel yang digunakan adalah tikus putih strain wistar (Rattus norvegicus strain wistar) dengan berat 180-200 gram dan berusia 2-3 bulan dengan kondisi sehat yang ditandai dengan gerakan yang aktif dan mata yang jernih. Pada penelitian ini terdapat 4 kelompok perlakuan yaitu satu kelompok kontrol dan tiga kelompok perlakuan (tikus yang diinduksi dengan formalin dengan dosis 0, 20, 40, dan 80 ppm). Dosis tersebut berdasarkan penelitian terdahulu dan telah dibuktikan melalui studi eksplorasi secara subakut (4 minggu) terhadap tikus putih strain wistar (Rattus norvegicus strain wistar). Estimasi besarnya sampel yang digunakan pada penelitian ini adalah sesuai dengan rumus berikut :

$$
\begin{aligned}
(\mathrm{t}-1)(\mathrm{p}-1) & =15 \\
(\mathrm{t}-1)(4-1) & =15 \\
3 \mathrm{t}-3 & =15 \\
3 \mathrm{t} & =18 \\
\mathrm{t} & =6
\end{aligned}
$$

\section{PROSEDUR PENELITIAN}

\begin{tabular}{|c|c|c|c|}
\hline Grup 1 & Grup 2 & Grup 3 & Grup 4 \\
\hline \multirow{3}{*}{ Kontrol } & Formalin & Formalin & Formalin \\
\hline & Cair & Cair & Cair \\
\hline & 20 ppm & $40 \mathrm{ppm}$ & 80 ppm \\
\hline \multicolumn{4}{|c|}{ Selama 4 minggu } \\
\hline & \multicolumn{2}{|c|}{ D } & \\
\hline & \multicolumn{2}{|c|}{ Tikus Dimatikan } & \\
\hline
\end{tabular}

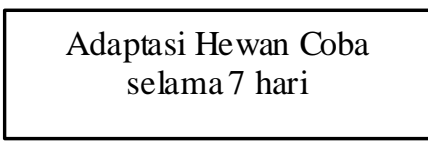

I

Pemaparan Formalin

B

Pengambilan organ lambung

dengan cara :

- Perut tikus dibedah

- Pengambilan lambung tikus, dipotong bagian proximal setinggi pre-kardiak dan bagian distal setinggi post-pilorus

- Bagian yang akan dibuat sediaan adalah kardiak.

B

Pembuatan sediaan dan pewarnaan HE

\section{I}

$$
\begin{aligned}
& \text { Pemeriksaan Histopatologi } \\
& \text { dengan cara : } \\
& \text { Penghitungan jumlah sel mukosa } \\
& \text { lambung bagian kardiak yang } \\
& \text { mengalami hiperplasia }
\end{aligned}
$$

\section{I}

\begin{tabular}{|l|}
\hline \multicolumn{1}{|c|}{ Analisa Data } \\
Menggunakan uji ANOVA, \\
Homogenitas, Korelasi, Regresi \\
\hline
\end{tabular}




\section{PENGAMATAN HASIL}

Sediaan diamati dengan mikroskop cahaya dengan pembesaran $100 \mathrm{X}$ dan $400 \mathrm{X}$ untuk mengamati dan menghitung sel yang hiperplasia pada 5 lapang pandang dengan menggunakan mikrometer.

\section{HASIL PENELITIAN}

Gambaran makroskopik
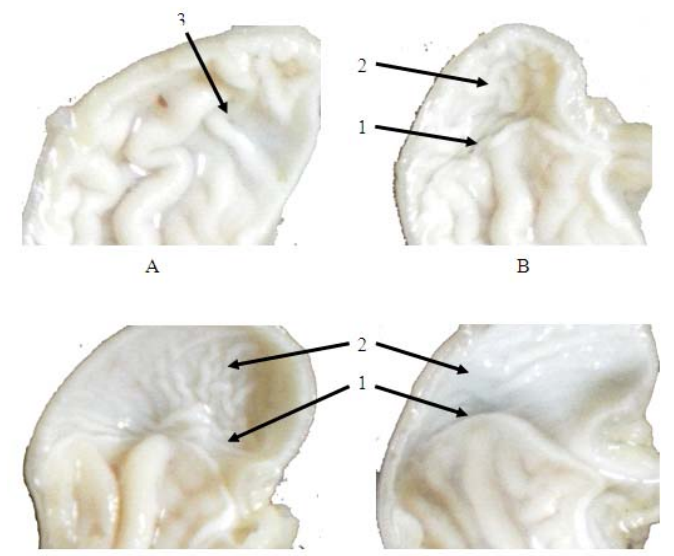

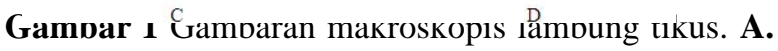
Kelompok 1 (formalin 0 ppm), lambung tikus tampak normal dengan rugae yang masih utuh. B. Kelompok 2 (formalin 20 ppm), lambung tikus tampak tidak normal dengan rugae yang rusak. C. Kelompok 3 (formalin 40 ppm), lambung tikus tampak tidak normal dengan rugae yang rusak dan kerusakan lebih luas dari perlakuan sebelumnya. D. kelompok 4 (formalin 80 ppm), lambung tikus tampak tidak normal dengan rugae yang rusak dan kerusakan lebih luas dan dalam dari perlakuan sebelumnya. (1) Batas antara mukosa normal dengan abnormal. (2) Bagian fundus yang mengalami kerusahan (menjadi licin). (3) Bagian fundus dengan rugae yang utuh (normal)

\section{Gambaran Mikroskopik}
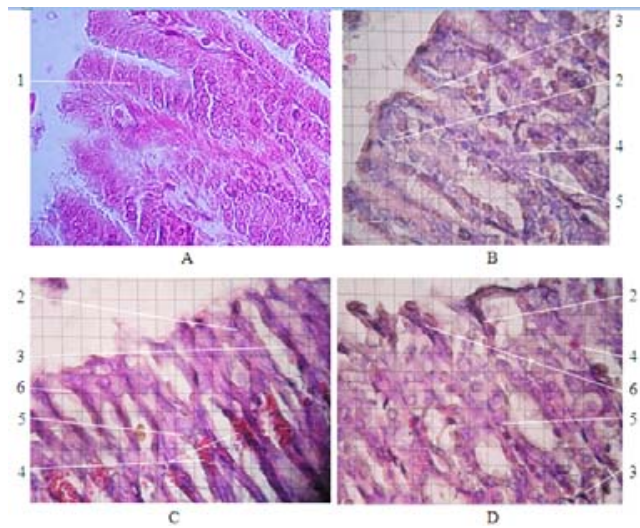

Gambar 2 Gambaran mikroskopis lambung tikus. A. Kelompok 1 (formalin 0 ppm), gambaran epitel columnar simplex tampak normal. B. Kelompok 2 (formalin 20 ppm), C. Kelompok 3 (formalin 40 ppm), D. kelompok 4 (formalin 80 ppm). Pada gambar B, C, D tampak adanya sel hiperplasia, hipertropi, atropi, dan muncul sel radang. (1) Sel epitel columnar simplex pada mukosa lambung. (2) Sel hipertropi,ditandai dengan inti sel (tercat gelap) yang membesar. (3) Sel hiperplasia, ditandai dengan adanya sel yang di antara sel normal. (4) Sel radang, berwarna paling merah. (5) Sel atropi, ditandai dengan insi sel yang mengecil. Serta pada gambar $\mathbf{C}$ dan $\mathbf{D}$ didapatkan sel mertaplasia (6), ditandai dengan berubahnya sel columnar simplex menjadi sel squamous simplex.

\section{Penelitian dengan Menggunakan Alat Bantu Mikrometer}

Tabel 1 Tingkat Kerusakan Lambung (\%) Terhadap Berbagai Perlakuan.

\begin{tabular}{|c|c|c|c|}
\hline Dosis & $\mathbf{N}$ & Jenis sel & $\begin{array}{c}\text { Rerata } \\
\text { Persentase } \\
\text { sel }\end{array}$ \\
\hline \multirow[t]{4}{*}{$0 \mathrm{ppm}$} & \multirow[t]{4}{*}{6} & hiperplasia & 0.24 \\
\hline & & hipertropi & 0.14 \\
\hline & & atropi & 0.22 \\
\hline & & radang & 2.11 \\
\hline \multirow[t]{4}{*}{$20 \mathrm{ppm}$} & \multirow[t]{4}{*}{6} & hiperplasia & 28.99 \\
\hline & & hipertropi & 31.09 \\
\hline & & atropi & 22.17 \\
\hline & & radang & 19.41 \\
\hline \multirow[t]{4}{*}{$40 \mathrm{ppm}$} & \multirow[t]{4}{*}{6} & hiperplasia & 30.45 \\
\hline & & hipertropi & 26.95 \\
\hline & & atropi & 27.70 \\
\hline & & radang & 21.56 \\
\hline \multirow[t]{4}{*}{$80 \mathrm{ppm}$} & \multirow[t]{4}{*}{6} & hiperplasia & 25.87 \\
\hline & & hipertropi & 21.11 \\
\hline & & atropi & 29.83 \\
\hline & & radang & 41.53 \\
\hline
\end{tabular}




\section{Pembahasan}

Seperti halnya yang terjadi di jaringan tubuh yang lain, lambung juga dapat mengalami keadaan patologis, seperti terjadi hipertropi, atropi, maupun hiperplasia sel. Hipertropi merupakan pembesaran ukuran sel tanpa pembelahan sel, atropi merupakan mengecilnya ukuran suatu organ atau sel, dan hiperplasia merupakan penambahan jumlah sel dengan mitosis. ${ }^{13,11,18,16}$ Hiperplasia terjadi bila sel - sel suatu jaringan terangsang untuk menjalani pembelahan sel sehingga menambah jumlah sel, hipertropi disebabkan oleh peningkatan jumlah sitoplasma organel sitoplasma di dalam sel. Pada sel - sel sekretorik, aparatus sintetik - mencakup retikulum endoplasma, ribosom, dan zona golgi - menjadi menonjol. Pada sel kontraktil seperti serabut otot, terdapat penambahan ukuran miofibril sitoplasma, Atropi merupakan berkurangnya jumlah sitoplasma dan jumlah organel sitoplasma dan jumlah organel sitoplasma serta biasanya terkait dengan penurunan metabolisme. Organel yang berdegenerasi diambil vakuola lisosom untuk menjalani degradasi enzimatik (autofagi). Membran organel yang tersisa sering terkumpul di dalam sitoplasma sebagai pigmen lipofusin coklat. Pengurangan jumlah sel disebabkan oleh ketidakseimbangan proliferasi dan kematian sel dalam jangka waktu lama. ${ }^{2}$ Munculnya sel hiperplasia, hipertropi, atropi, dan radang merupakan suatu mekanisme adaptasi sel terhadap lingkungan, yang dalam hal ini respon terhadap cedera kimia yang disebabkan formalin. Farmakodinamik formaldehyde adalah dengan menekan fungsi sel-sel dan mengakibatkan nekrosis jaringan. Farmakokinetik formaldehyde adalah diserap melalui semua jalan saluran lambung/usus serta paru-paru dan dioksidasi menjadi asam formic dan bagian kecil methyl format (dibentuk methyl). Asam formic di lambung akan berikatan secara stabil dengan makromolekul seluler protein DNA yang dapat berupa ikatan silang (cross linked) sehingga terjadi kelainan pada mukosa lambung seperti hiperkeratosis, papillomatous hiperplasia, dan fokal atropik inflamasi kelenjar gaster. ${ }^{6}$

Pengamatan makroskopik pada perlakuan 2, 3, 4 (pemberian formalin 20ppm, $40 \mathrm{ppm}, 80 \mathrm{ppm}$ ) dapat dilihat bahwa terjadi lesi yang berupa erosi pada bagian fundus. ${ }^{10}$ Erosi merupakan pengelupasan permukaan epitel dengan bagian dalam mukosa tetap utuh. ${ }^{2}$
Mukosa kardiak dan fundus rentan terkena lesi karena pada daerah tersebut kelenjarnya dibentuk oleh sel parietal (oxyntic) yang mensekresi asam dan sel utama (zimogen atau peptik) yang mensekresi pepsin, sehingga apabila terjadi destruksi sawar mukosa lambung akan terjadi difusi balik lebih besar dari daerah lain., ${ }^{2,10}$ Dengan semakin besar dosis formalin yang diberikan maka lesi juga semakin luas. Hal ini disebabkan formalin dapat mengubah permeabilitas sawar epitel mukosa lambung, sehingga memungkinkan difusi balik asam klorida yang mengakibatkan kerusakan jaringan. Selanjutnya histamin dikeluarkan, merangsang sekresi asam dan pepsin lebih lanjut dan meningkatkan permeabilitas kapiler terhadap protein. Mukosa menjadi edema, dan sejumlah besar protein plasma dapat hilang. Mukosa kapiler dapat rusak, mengakibatkan terjadinya hemoragi interstitial dan perdarahan. ${ }^{10}$

Selanjutnya pengamatan secara mikroskopik pada perlakuan 2, 3, 4 (pemberian formalin 20 ppm, 40 ppm, 80 ppm) didapatkan sel hiperplasia, hipertropi, atropi, dan sel radang. Hal tersebut merupakan respon jaringan terhadap agen kimia, dalam hal ini formalin, yang dapat mengakibatkan lesi pada jaringan. Lesi jaringan dapat terjadi pada sel - sel parenkim (lesi langsung) dan jaringan interstitial (lesi tak langsung). Akibatnya dapat terjadi degenerasi sel parenkim dan interstitial bahkan bisa terjadi nekrosis. ${ }^{2}$ Selain itu diduga karena formalin bisa menyebabkan terikatnya DNA oleh protein, sehingga mengganggu ekspresi genetik yang normal. ${ }^{22}$

Perubahan DNA, yang merubah ekspresi genetik normal, dapat menyebabkan reaksi autoimunitas yang secara langsung menyerang sel parietal pada korpus dan fundus lambung yang mensekresikan faktor intrinsik dan asam. Hal ini dapat menyebabkan anemia pernisiosa (kekurangan vitamin B12). Mekanisme autoimun: (1) respon yang diperantarai sel $\mathrm{T}$ menyerang sel parietal, dan (2) respon humoral yang berkaitan dengan keberadaan 3 serum antibodi berbeda yaitu (a) dalam 90\% antibodi sel anti-parietal; (b) dalam 75\% antibodi penghambat faktor intrinsik; dan (c) dalam $50 \%$ antibodi pengikat faktor intrinsik (berikatan dengan kompleks faktor intrinsik-vitamin B12, mencegah absorpsi vitamin B12). Reaksi autoimun bermanifestasi sebagai serbukan limfoplasmasitik pada mukosa sekitar sel parietal, yang secara progesif berkurang. Sehingga 
mukosa fundus dan korpus menipis dan kelenjar kelenjar dikelilingi oleh sel mukus yang mendominasi. ${ }^{2}$

Pada penelitian ini sel hiperplasia cenderung meningkat pada pemberian dosis formalin $0 \mathrm{ppm}-40 \mathrm{ppm}$, namun pada pemberian dosis formalin $80 \mathrm{ppm}$ justru mengalami penurunan. Hal ini diduga sel hiperplasia pada kelompok 4 (formalin 80 ppm) sudah mulai metaplasia. Metaplasia (transdiferensiasi) merupakan perubahan dari satu jenis sel yang sudah selesai berdiferensiasi (epitel atau mesenkim) ke jenis sel lain dengan diferensiasi penuh. Metaplasia mencerminkan respon penyesuaian jaringan terhadap pengaruh lingkungan, yang dalam hal ini pengaruh formalin, dan diduga diakibatkan oleh pengaktifan dan/atau menjadi kurang aktifnya sekelompok gen yang yang terlibat dalam pemeliharaan diferensiasi seluler. Jaringan metaplastik dapat bertahan dengan lebih baik terhadap perubahan lingkungan yang merugikan. ${ }^{16}$

Selanjutnya muncul hipertropi yang meningkat pada pemberian formalin dosis $20 \mathrm{ppm}$ kemudian cenderung menurun mulai dosis $40 \mathrm{ppm}$ hingga $80 \mathrm{ppm}$. Hal ini mungkin disebabkan sel yang hipertropi sudah maksimal sehingga sel menjadi lisis (apoptosis). Pada beberapa keadaan tertentu, sel permanen akan meningkatkan kandungan DNA-nya (ploidi) sewaktu hipertropi, walaupun sel tetap berada pada fase $G_{2}$ dari siklus sel tanpa mengalami mitosis. ${ }^{16}$

Sel atropi yang muncul pada penelitian ini cenderung meningkat terhadap pemberian dosis formalin yang semakin besar. Atropi merupakan respon penyesuaian yang penting terhadap berkurangnya permintaan tubuh berkaitan dengan fungsi organ atau sel tertentu. Terjadinya atropi tidak hanya berhentinya pertumbuhan tetapi juga pengurangan yang aktif dari ukuran sel dan/atau jumlah sel, yang diperantarai oleh apoptosis. Terjadinya sel atropi pada penelitian ini diduga karena adanya (1) hilangnya pasokan darah akibat dari terjepitnya kapiler oleh sel yang hipertropi maupun hiperplasia sehingga terjadi anoksia jaringan; (2) adanya 'tekanan' dari sel sekitar yang mengalami hipertropi maupun hiperplasia sehingga terjadi hipoksia jaringan setempat. ${ }^{16}$ Hal ini juga dapat menjelaskan tentang munculnya sel hipertropi dan sel atropi secara bersamaan (dalam satu sediaan).
Sel radang muncul akibat respon selular yang dilakukan tubuh karena adanya agen asing. Peradangan dalam hal ini adalah peradangan akut yang ditandai dengan emigrasi aktif sel - sel radang dari darah ke arah cedera. Di dalam pembuluh darah yang normal, elemen - elemen selular darah tertahan di dalam aliran aksial sentral, terpisah dari permukaan endotel oleh suatu zona plasma. Pemisahan ini bergantung pada aliran darah yang normal, yang menciptakan gaya - gaya fisik yang cenderung menahan partikel selular yang paling berat di bagian tengah pembuluh darah. Ketika aliran darah di dalam pembuluh darah yang mengalami dilatasi menurun pada peradangan akut, keteraturan aliran darah terganggu. Eritrosit membentuk agregat besar (rouleaux) dalam suatu fenomena yang disebut sludging (pengendapan). Akibatnya, leukosit bergerak ke perifer bersentuhan dengan endotel (marginasi), dan kemudian banyak yang menempel. Penempelan merupakan suatu proses normal yang amat meningkat pada peradangan sebagai akibat meningkatnya ekspresi berbagai molekul perekat sel (CAMs = cell adhesion molecules). Ekspresi beta 2 integrin (kompleks CD11CD18), yang meliputi antigen fungsi leukosit-1 (LFA1), mempertinggi kerja faktor - faktor kemotaktik seperti C5a (komplemen “anafilatoksin”) dan leukotrien LTB4. CAMs komplementer pada sel endotel diregulasi naik juga oleh kerja interleukin-1 (IL-1) dan TNF (tumor necrosis factor, yang tidak terbatas pada tumor); CAMs ini meliputi ICAM 1, ICAM 2, dan ELAM-1 (endothelial leukocyte adhesion molecule). LAM-1, yang memperlancar lewatnya limfosit melintasi "high endothelial vesicles" ke dalam kelenjar limfe, juga memainkan peranan pada emigrasi neutrofil dan limfosit pada peradangan. Neutrofil dengan aktif meninggalkan pembuluh darah melalui persambungan interselular dan melintasi membran basalis untuk mencapai ruang interstitial. ${ }^{2}$ Dalam hal ini sel radang cenderung meningkat terhadap pemberian dosis formalin yang semakin besar. Keadaan tersebut sesuai dengan teori yang telah dipaparkan sebelumnya. Apabila setiap ada agen asing maka tubuh akan selalu memberikan respon.

Pada penelitian yang lain, Lambung tikus yang dipapar 25mg/kg (yang setara dengan $25 \mathrm{ppm}$ ) secara kronik (dalam waktu 2 tahun) terjadi hiperkeratosis pada permukaannya, fokal atropik inflamasi pada kelenjar lambung, dan papillomatous hiperplasia. ${ }^{20}$ Penelitian 
tentang formalin juga pernah dilakukan terhadap tikus putih. Dalam waktu 4 minggu, tikus dipapar dengan formalin dengan dosis $0,5,25,125 \mathrm{mg} / \mathrm{Kg} / \mathrm{hari}$ (setara dengan 0 ppm, 5 ppm, 25 ppm, dan 125 ppm). Pada dosis terbesar diperoleh hasil terjadi penurunan asupan makanan dan minuman dari tikus serta perubahan histopatologi berupa fokal hiperkeratosis dan hiperplasia pada permukaan mukosa lambung. ${ }^{22}$

Dalam penelitian ini dapat dilihat terjadinya peningkatan yang sangat menanjak antara dosis $0 \mathrm{ppm}$ dengan dosis 20 ppm pada masing - masing parameter. Hal ini diduga masih ada dosis antara $0 \mathrm{ppm}$ dan $20 \mathrm{ppm}$ yang dapat menimbulkan pengaruh lesi terhadap mukosa lambung tikus.

Dari berbagai fakta yang ditemukan pada penelitian ini dan melalui kajian teoritik, maka hipotesa tentang pemberian formalin peroral subakut dapat menyebabkan lesi pada mukosa lambung tikus putih strain wistar (Rattus norvegicus strain wistar) terbukti, namun masih memerlukan penelitian lebih lanjut untuk menentukan mekanisme yang sebenarnya dari formalin dalam menyebabkan perubahan sel mukosa lambung.

\section{KESIMPULAN}

Formalin dapat merusak lambung yang dibuktikan dengan berubahnya sel mukosanya menjadi hiperplasia, hipertropi, atropi, dan munculnya radang.

\section{REFERENSI}

1. Badan Pengawasan Obat dan Makanan.2005. Formalin Di Plastik Makanan. (online) (http:// www.gizi.net di kutip dari BPOM Jakarta 2005 diakses 5 mar 2008)

2. Candrasoma, Parakrama dan Taylor, Clive R.2006. Ringkasan Patologi Anatomi Edisi 2.EGC. Jakarta. Hal 1; 37 - 38; 231 - 233; 522 - 523

3. Cotran, Ramzi s.;Kumar, Vinay;Collins, Tucker. 1999. Robbins Pathology Basis of Disease sixth edition.W.B. SAUNDERS COMPANY. Philadelphia page :32-33
4. Darmansjah, Iwan.2000.Toksikologi; dalam buku Farmakologi dan Terapi.Universitas Indonesia. Jakarta Hal 765 - 766

5. Doyle, Shari K. 2001. Priority Substance List Assessment Report: Formaldehyde. Environment Canada, Health Canada. Ottawa

6. Federal-Provincial-Territorial Committee on Drinking Water.2003. Formaldehyde. (online) (http://www.hcsc.gc.ca/ewh-semt/alt_formats/hecs-sesc/pdf/ pubs/ water-eau/formaldehyde/formaldehyde_e.pdf diakses 25 feb 2008)

7. Franklin, Craig L.1998. Research Animal Diagnostic and Investigative.Laboratory

8. University of Missouri. Columbia. (online) (www.aclad.org diakses 28 mei 2008)

9. Hirlan.2001.Gastritis; dalam buku Ilmu Penyakit Dalam Jilid 2 Edisi Ketiga.Jakarta Hal 127 - 131

10.Lindseth, Glenda N.2006.Gangguan Lambung dan Duodenum; dalam buku Patofisiologi Konsep Klinis Proses - Proses Penyakit Edisi 6.EGC.Jakarta. Hal : 424

11.Miller, Leslie W.; Saladin, Kenneth S. 2004. Anatomy \& physiology: the unity of form and function. Boston: McGraw-Hill Higher Education (online)( http://www.cliffsnotes.com/WileyCDA/ CliffsReviewTopic/The-Stomach.topicArticleId22032,articleId-22012.html diakses 28 mei 2008)

12.National Cancer Institude. 2000. Stomach. (online) (http://seer.cancer.gov/publications/ethnicity/ stomach.pdf diakses 5 maret 2008)

13.Soybel DI.2005. Anatomy and physiology of the stomach. (online) ( http://www.cmaj.ca/cgi/reprint/ 175/12)

14.Supranto, J.2007.Teknik sampling survey \& eksperimen.PT Rineka Cipta.Jakarta hal : 217

15.Tucker, Samuel P., Ph.D.1998.Formaldehyde. NIOSH Manual of Analytical Methods (NMAM), Fourth 
Edition.New York (online) (www.cdc.gov/niosh/ database.html diakses 28 mei 2008)

16.Underwood, J.C.E.1999.Patologi Umum dan Sistemik edisi 2.EGC.Jakarta hal: 432-442

17.Vargova, M.2003. Subacute Immunotoxicity Study of Formaldehyde in Male Rats. (online)( http:// w w w. i n for m a w or ld. c o m / s m p p / content $\sim$ content $=\mathrm{a} 786804322 \sim \mathrm{db}=$ all $\sim$ order=page diakses 10 juni 2008)

18.Voltaire.2005.stomach.(online)( http://www.uwgi.org/ gut/pdf/stomach.pdf diakses 5 maret 2008)

19.Wehbi, Mohammad. 2006. Gastitis Acute. (online) (http://www.emedicine.com/med/gastrostomach.htm diakses 27 mei 2008)

20.Wilbur, Sharon.1999.ATSDR Minimal Risk Levels And Worksheets.Formaldehyde. Georgia (online)( www.atsdr.cdc.gov/mhmi/mmg111.html diakses 28 mei 2008)

21.World Health Organisation.2001.Formaldehyde in Drinking-water.New York page: 3-5

22.World Health Organisation.2005. Formaldehyde in drinking-water. Background document for development of WHO Guidelines for drinking-water quality. Geneva (online) (http://www.who.int/ water_sanitation_health/dwq/chemicals/ formaldehyde130605.pdf diakses 25 februari 2008)

23.World Health Organization.2004. INDONESIA Environmental Health Country Profile.(online)( http://www.wpro.who.int/NR/rdonlyres/AE91F862B F F E - 4 F E D - 806 D - 34 F 7202 F F D 13 / 0 / indonesia_ehcp_19Nov2004.pdf diakses 28 mei 2008)

24.World Health Organization.2006. The Impact of Cancer In Your Country - Data Tables.(online)( http://www.who.int/infobase/report.aspx? rid $=153 \&$ iso $=$ IDN\&generateResults $=$ Generate + Report diakses 9 juni 2008) 